Coopetition in innovation ecosystems: A comparative analysis of knowledge transfer configurations

\author{
Emily Bacon
}

Michael D. Williams

Gareth Davies

School of Management

Swansea University

Bay Campus

Swansea

SA1 8EN

UK 


\title{
Coopetition in innovation ecosystems: A comparative analysis of knowledge transfer configurations
}

\begin{abstract}
The effective management of knowledge exchange is critical for open innovation in ecosystem contexts where organizations may partner with potential competitors. This study contributes to existing knowledge by detecting the conditions for knowledge transfer success between both coopetitive and non-competitive ecosystem partners. The study uses a qualitative approach. Semi-structured interviews were conducted with 20 stakeholders across multi-industry ecosystems to compare the presence of knowledge transfer conditions between competitors and non-competitors. Through fuzzy-set qualitative comparative analysis (fsQCA), configurational recipes of conditions were identified, revealing the distinct configurations required of either coopetitive or non-competitive partnerships in the context of innovation ecosystems. The findings show the need for organizations to tailor knowledge exchange practices to the competitive nature of each relationship. Notable theoretical and practical implications are provided for ecosystem stakeholders that engage in coopetitive partnerships to develop innovations.
\end{abstract}

Keywords: Coopetition; Ecosystem; Open innovation; FsQCA; Knowledge transfer 


\section{Introduction}

In an increasingly competitive, interconnected economy, in-house research and development $(\mathrm{R} \& \mathrm{D})$ activities are being replaced by more open approaches to developing innovations (Chesbrough, 2003; Simpson, 2019). Firms increasingly pursue partnerships with external knowledge sources that possess more advanced expertise. Such sources may consist of potential competitors, whose similarities make them more suitable for sharing complementary knowledge assets (Gnyawali \& Park, 2009). It is argued that organizational innovativeness relies on such partnerships, which involve simultaneous collaboration and competition, amalgamated to form "coopetition" (Bouncken \& Kraus, 2013). Identified as a "secret of success" (Stockdale, 2015), coopetitive partnerships increase innovative capacity (Leitão \& Pereira, 2015; Ribeiro-Soriano, Roig-Tierno, \& Mas-Tur, 2016; Ritala \& Hurmelinna-Laukkanen, 2013), with some innovations proving not to be feasible without coopetition (Baierl, Anokhin, \& Grichnik, 2016). Innovation ecosystems offer multiple opportunities for knowledge exchange with both non-competitive and competitive partners. Comprising startups, small businesses, universities, and multinational corporations (Carayannis \& Campbell, 2009), ecosystems are characterized by coopetition (Selander, Henfridsson, \& Svahn, 2010) and occupy the core of open innovation activities (Bogers, Chesbrough, \& Moedas, 2018).

Effective knowledge sharing is an important component of coopetitive ecosystem partnerships. It adds value to both partner organizations (Chin, Chan, \& Lam, 2008) and is a critical factor in maintaining such relationships (Chua, 2003). However, knowledge exchange in coopetitive partnerships entails numerous complexities (Bouncken, Gast, Kraus, \& Bogers, 2015) necessitating efficient management of the process (Baumard, 2009). Gast, Filser, Gundolf, and Kraus (2015) argue that mechanisms should be implemented to enable and sustain the sharing of necessary knowledge in coopetitive partnerships, acting as a preventive 
measure for unwanted imitation and knowledge leakage. Thus, successful knowledge management is vital in contexts where competitors leverage the skills and resources of interorganizational partners (Oxley \& Sampson, 2004). Despite the importance of this process, few studies have examined effective knowledge transfer for coopetitive partners in innovation ecosystems (Bengtsson \& Raza-Ullah, 2016; Charleton, Gnyawali, \& Galavan, 2018; Czachon \& Mucha-Kuś, 2014; Dorn, Schweiger, \& Albers, 2016), justifying the need for a more comprehensive examination of these domains. Moreover, while the notion of coopetition has received widespread attention in recent years (Baierl et al., 2016; Bengtsson \& Kock, 2014; Bouncken \& Kraus, 2013; Yami, Castaldo, Dagnino, \& Le Roy, 2010), scholars have noted that coopetition research is fragmented and limited, with some research areas being explored in depth yet others ignored (Ritala, Kraus, \& Bouncken, 2016).

This study remedies the absence of such research by making the following contributions. First, because few analyses have adequately tackled the question of how open innovation fosters coopetitive benefits (Bouncken et al., 2015), this research contributes to the growing body of literature on coopetition in open innovation ecosystems. Second, although $50 \%$ of all new alliances are between competitors (Bengtsson, Raza-Ullah, \& Vanyushyn, 2016; Harbison \& Pekar, 1998), the remaining proportion of interorganizational partnerships are non-competitive. Because these partnership types exhibit unique characteristics (Gnyawali \& Charleton, 2018), detecting symmetrical distinctions in the knowledge transfer practices of these partners is necessary to further deconstruct how success can be achieved. Moreover, while research has begun to provide greater insights into interorganizational knowledge management in coopetition, further work is needed to ascertain the relationship-level and firm-level components of knowledge management for coopetition (Tidström, 2018). In view of this requirement, this study uses fuzzy-set qualitative comparative analysis (fsQCA) to detect how knowledge-, firm-, and relationship- 
level characteristics contribute to knowledge transfer success in both coopetitive and noncompetitive partnerships. The application of fsQCA in this study constitutes a key contribution, following recommendations by Devece, Ribeiro-Soriano, and Palacios-Marqués (2019) and Ritala et al. (2016) to apply such novel analytical techniques to coopetition research. Doing so enables a comparative analysis of the conditions of knowledge transfer success in coopetitive versus non-competitive partnerships, contributing to the coopetition literature by addressing the absence of this form of analysis. Accordingly, the following research question is posed: How do the conditions for knowledge transfer success differ in coopetitive versus non-competitive ecosystem partnerships?

The remainder of this paper is structured as follows. Section 2 reviews the literature underlying this research. Section 3 presents the theoretical framework. Section 4 describes the sample, materials, and methods used in this study and justifies the application of fsQCA. Section 5 discusses the results of the fsQCA procedure and examines the main findings. Theoretical and managerial implications, along with study limitations and recommendations for future research, are provided in Section 6.

\section{Literature review}

Combining "simultaneous competition and cooperation," coopetition involves partnerships between firms with "value creation intent" (Gnyawali \& Charleton, 2018, p.2513). Many definitions emphasize the combination of the terms "cooperation" and “competition” (Bengtsson \& Kock, 2000; Fernandez, Chiambaretto, Le Roy, \& Czakon, 2018; Leitão \& Pereira, 2015; Yami \& Nemeh, 2014). The fact that the terms are harmonious and can occur concomitantly is stressed (Ritala et al., 2016). Although they are frequently merged, cooperation and competition entail separate logics. Cooperation entails the pursuit of collective interests and benefits, whereas competition involves private interests and 
opportunistic behavior (Bengtsson et al., 2016). Competitors are identified as organizational actors who produce and market the same products (Bengtsson \& Kock, 2000).

Choosing either a competitor or a non-competitor as a potential innovation partner commonly depends on the requirements of the partnership and the partner's ability to adhere to such requirements. Non-competitive partnerships are often sought for the provision of niche knowledge (Bougrain \& Haudeville, 2002), complementary resources (Prashantham \& Birkinshaw, 2008), or research-based knowledge (Nieto \& Santamaría, 2007). Alternatively, organizations may seek a coopetitive partnership, the rationale for which varies. Commonly, coopetitive partnerships may derive from a need to carry out research and establish standards (Gueguen, 2009; Tether, 2002), address common problems (Nieto \& Santamaría, 2007), achieve economies of scale (Gnyawali \& Park, 2011), enter new markets (Gnyawali \& Park, 2009), or share risks associated with introducing new products (Bouncken et al., 2015; Ritala \& Hurmelinna-Laukkanen, 2009; Tether, 2002). Coopetitive partnerships are more likely than non-competitive partnerships to generate novel products (Ritala \& HurmelinnaLaukkanen, 2009).

Research has further shown that engaging with a wide range of competitors in an innovation ecosystem approach provides palpable benefits in the context of coopetition, including providing greater opportunities to observe and learn from the behaviors of competitors and facilitating open innovation through greater access to knowledge flows (Baierl et al., 2016). Numerous studies have illuminated the relationship between coopetition and innovation (Bouncken \& Kraus, 2013; Gnyawali \& Park, 2011; Leitão \& Pereira, 2015; Ribeiro-Soriano et al., 2016; Ritala \& Hurmelinna-Laukkanen, 2013; Ritala et al., 2016; Yami \& Nemeh, 2014). Open innovation itself shares an important link with coopetition: simultaneous cooperative and competitive engagement between organizations relates strongly to the coupled mode of open innovation (Enkel, Gassmann, \& Chesbrough, 2009), whereby 
both outside-in and inside-out processes are employed in the innovation process. Thus, the relationship between open innovation and coopetition is an emergent area of notable interest (Ritala et al., 2016).

Coopetition has been identified as an integral component of open innovation ecosystems and is pursued in these contexts as a result of various lines of inquiry, including responding to threats, encouraging technology domination, and facilitating the diffusion of specialized activities (Gueguen, 2009). This importance has been echoed in previous empirical analyses of coopetition within ecosystems. Ritala, Agouridas, Assimakopoulos, and Gies (2013) investigated how leading firms facilitate value creation and capture with competitors across their ecosystems. Basole, Park, and Barnett (2015) demonstrated that coopetition in ICT ecosystems remains prevalent, with growing levels of value capture. Ritala, Golnam, and Wegmann (2014) analyzed the application of coopetition-based business models for value creation and capture in ecosystem contexts. Selander et al. (2010) explored the governance of coopetitive ecosystem relationships in the context of digital innovation. Gueguen and Isckia (2011) found that coopetitive strategies are particularly relevant in ecosystem contexts, with indirect coopetition also characterizing the ecosystem approach. Ansari, Garud, and Kumaraswamy (2016) analyzed how disruptive innovators negotiate coopetitive tensions within their ecosystems. Thus, research exploring coopetition in innovation ecosystems has progressed substantially in recent years. However, ecosystemlevel analyses are still scarce (Ritala et al., 2016), belying the importance of these approaches to coopetition. Despite increasingly prevalent discourses about the positive interrelations between coopetition and innovation (Devece et al., 2019), few studies have evaluated the mechanisms employed by organizations for effective management of the knowledge sharing process in these contexts (Gast et al., 2015). With innovation ecosystems occupying an emergent area of interest in the coopetition literature, further explorations are required to 
solidify the link between the two constructs, particularly because coopetitive and innovative capabilities are more important in complex, dynamic environments such as ecosystems (Roig-Tierno et al., 2018). This study addresses this gap by identifying the knowledge transfer conditions for coopetitive ecosystem partnerships.

\section{Theoretical framework}

According to a recent review (Devece et al., 2019), numerous theoretical frameworks have been applied in coopetition research, including game theory and the resource-based view. This broad use of theoretical approaches presents difficulties in relation to establishing a common or generally accepted theoretical lens for coopetition analyses. Moreover, knowledge sharing in coopetitive contexts requires a different theoretical framework depending on the level of analysis (Devece et al., 2019). Because of such inconsistencies, this study uses a previously validated theoretical lens that is appropriate for analyzing knowledge transfer success at the individual level in coopetitive contexts. This theoretical lens is based on the conceptual framework developed by Bacon, Williams, and Davies (2019). The framework reflects the importance of specific knowledge transfer conditions, identified through a review of the interorganizational knowledge transfer literature (Bacon et al., 2019). The most common conditions (i.e., with a citation frequency of 10 or higher) identified in the review are explored in this section. The conditions are classified into three groups: knowledge, relationship, and organizational characteristics.

\subsection{Knowledge characteristics}

The interorganizational literature reports that knowledge characteristics accelerate the transfer process (Easterby-Smith, Lyles, \& Tsang, 2008). Knowledge is often typified as information-based and codifiable (explicit) or experience-based and personal (tacit; Nonaka 
$\&$ Takeuchi, 1995). Because of the greater ease of translation, explicit knowledge is argued to be transferred more readily than its tacit counterpart (Al-Salti \& Hackney, 2011). The degree of understanding possessed by the recipient organization thus depends on the nature of the knowledge. Accordingly, tacit versus explicit knowledge and an understanding of that knowledge are found to facilitate knowledge transfer. The framework applied in this research hence extends that of Bacon et al. (2019) by separating knowledge type into these separate components.

A further knowledge characteristic identified as affecting the transfer process is causal ambiguity, which involves a lack of clarity regarding the origins and components of knowledge (Szulanski, 1996). High causal ambiguity requires greater explanations, decelerating the transfer process (Al-Salti \& Hackney, 2011). Tacit versus explicit knowledge, understanding, and low causal ambiguity formulate the knowledge category.

\subsection{Relationship characteristics}

The literature further posits that relationship characteristics between innovation partners encourage knowledge transfer. Enjoying the greatest popularity in the literature, trust involves an expectation that the innovation partner will fulfill their obligations as a transferee of knowledge (Inkpen, 1998). Trust is arguably a fundamental component of an ecosystem partnership because it encourages openness to communicate and share knowledge (Mazloomi Khamseh \& Jolly, 2008). Moreover, a trustworthy partnership is crucial to achieving successful coopetition (Chin et al., 2008; Thomason, Simendinger, \& Kiernan, 2013) because it enhances cooperative behavior and stimulates knowledge exchange (Planko, Chappin, Cramer, \& Hekkert, 2019). Trust is further identified as an enabler of relationship strength (Narteh, 2008), alluding to another relationship characteristic: strong ties. These ties between organizations act as channels for knowledge flow (Easterby-Smith et al., 2008), encouraging 
organizations to share more detailed knowledge and facilitating access to information (Narteh, 2008). Thus, an ecosystem that comprises strong partner ties is more likely to foster the successful exchange of high-quality knowledge (Van Wijk, Jansen, \& Lyles, 2008). Trust and tie strength therefore encompass the relationship characteristics cited as expediting knowledge transfer.

\subsection{Organizational characteristics}

Other conditions related to the recipient organization are also of relevance for knowledge transfer success. The degree of cultural congruency between organizations in terms of shared beliefs, values, and practices is argued to advance knowledge transfer (Mowery, Oxley, \& Silverman, 1996). Commonalities between a mutual vision and goals provide a crucial bonding mechanism (Van Wijk et al., 2008), encouraging organizations to become partners (Planko et al., 2019). Similarities between cultures thus underpin knowledge transfer success by delineating boundaries regarding the content and quality of knowledge (Narteh, 2008).

The willingness of the recipient organization to learn from an innovation partner is also cited as important for effective knowledge exchange (Inkpen, 1998). Learning does not occur automatically, and a determination and desire to achieve learning is therefore necessary (Mazloomi Khamseh \& Jolly, 2008). Commitment to learning knowledge from an ecosystem partner ultimately assists in its successful transfer (Al-Salti \& Hackney, 2011). However, this learning depends on the effective absorption of knowledge. The related concept of absorptive capacity is outlined as encompassing the recipient organization's ability to recognize the potential value of knowledge, diffuse it internally, and apply it beneficially (Cohen \& Levinthal, 1990). Research has shown the importance of absorptive capacity for coopetition (Fredrich, Bouncken, \& Kraus, 2019) by permitting organizations not only to absorb 
knowledge effectively but also to transmit that knowledge across organizational boundaries (Easterby-Smith et al., 2008). Organizational characteristics thus comprise cultural similarity, learning intent, and absorptive capacity.

\subsection{Combinations of conditions}

The conditions explored in the conceptual framework shed light on how successful knowledge transfer is underpinned. However, their association with success does not necessarily mean that their absence will correlate with the absence of this outcome. Consequently, the investigation of which causes contribute to a given outcome conveys little about which causes contribute to the absence of an outcome, necessitating separate asymmetric models (Woodside, 2014). This causal asymmetry (Fiss, 2011) is an underlying tenet of fsQCA, providing a fundamental rationale for its application in this study: the fsQCA method enables an analysis that illuminates how instances of the presence and absence of success can be achieved.

Moreover, the multitude of conditions cited as underpinning knowledge transfer success are likely to result in multiple ways to achieve this outcome in coopetitive and noncompetitive partnerships. Termed equifinality, the presence of multiple, mutually exclusive pathways for accomplishing a given outcome underpins fsQCA (Fiss, 2011). Studies have provided contradictory results regarding the configurational nature of the knowledge transfer conditions. Despite the essential nature of relationship-, firm-, and knowledge-specific characteristics, they may be combined in different causal combinations to explain the outcome of success. Although some of the literature indicates that certain relationship-, knowledge-, or firm-specific characteristics form combinatory associations for coopetition (Fredrich et al., 2019; Ritala \& Hurmelinna-Laukkanen, 2013; Planko et al., 2019), other research suggests that single conditions are of greater importance (Chin et al., 2008). These 
inconsistencies in findings thus reflect a need for a more definite investigation into the configurational nature of knowledge transfer conditions for coopetitive partnerships. The resulting conceptual model shows how the knowledge transfer conditions are expected to combine and overlap for the outcome of success (Figure 1).

Insert Figure 1 here.

\section{Material and methods}

\subsection{Analytical technique}

FsQCA was used to empirically analyze the conceptual framework. Its underlying tenets justify its suitability for this research. As outlined by Ragin (2009), fsQCA is a settheoretic approach that detects the underlying causal conditions across cases that contribute to the expression of a given outcome. FsQCA reflects attempts to integrate the best features of qualitative and quantitative research (Ragin, 2009) by marrying the in-depth analyses associated with qualitative research with the accessible evaluations provided by quantitative analyses to effectively allow substantial comparisons across cases (Greckhamer, Misangyi, Elms, \& Lacey, 2008). Cases are viewed as temporally and contextually embedded compositions of interrelated components rather than single entities (Pettigrew, 1990). FsQCA thus captures the diversity and heterogeneity of cases, in terms of their causally relevant conditions and contexts, by allowing cases to be compared as configurations (Ragin, 2009).

The configurational approach underpinning fsQCA is one of the fundamental justifications for selecting this method of analysis. This technique enables comparison of coopetitive versus non-competitive cases while generating highly representative characterizations of each case. It also enables detailed analyses that capture the heterogeneous nature of the partnerships explored in this study. 


\subsection{Sample}

To ascertain the conditions that are present in coopetitive and non-competitive partnerships, semi-structured telephone interviews were conducted with 20 members of an open innovation ecosystem. A snowball sampling strategy was employed (Goodman, 1961), and individuals from a large multinational services enterprise were contacted to request their perceptions of the conditions for knowledge transfer success. These participants then provided details of other suitable contacts across a variety of organisations, resulting in responses collected across a range of industries, including manufacturing, transport, technology, and finance.

Participants were placed into the coopetitive or non-competitive category following classification of the partnership type. The coopetitive category was composed of both multinational corporations and small businesses that were engaged in a partnership with an identified competitor. Participants in the non-competitive category were those whose company possessed no degree of competition with its innovation partner because they belonged to different industries or were of different organizational types.

\subsection{Interview schedule}

The interviews required participants to assess the presence of each condition on a 7point scale that applied the principles of a semantic differential approach (Osgood, Suci, \& Tannenbaum, 1957). Opposing adjectives were placed at either end of the scale to reflect the absence and presence of each condition. These scales were supplemented with additional questions asking participants to expand on their answers, allowing them to provide further information regarding each condition and generating a greater degree of freedom and flexibility in the responses. Table 1 displays the scales and their supplementary questions (adapted from Bacon et al., 2019). 
Insert Table 1 here.

This study used the definition of knowledge transfer success given by Bacon et al. (2019) to assess whether each partnership could be characterized as having successfully achieved this outcome. The proposed definition was the "active exchange of knowledge between organizations, involving measurable and effective knowledge absorption, application and satisfaction by the recipient organization" (p. 380). This definition was embedded in the interviews as a further semantic differential measurement, and individuals were asked to rate their extent of agreement with five statements corresponding to the five separate constituents of knowledge transfer success.

\subsection{FsQCA calibration}

FsQCA operates on the basis of each case's degree of membership in a given set. To establish degrees of membership, the data are calibrated into values ranging from 0 to 1 . The calibration procedure requires specification of the following threshold values: full membership in the outcome, full non-membership, and maximum ambiguity (Fiss, 2011). The value for full membership was set at 6 , the crossover point was set at 4.5 , and full nonmembership was set at 3 . The use of semantic differential scales to assess this data set enabled natural breakpoints contained in the scale to be used as the three threshold values, which is an accepted approach to calibration (Ordanini, Parasuraman, \& Rubera, 2014; Pappas, Kourouthanassis, Giannakos, \& Chrissikopoulos, 2016; Woodside, 2013).

The conditions Tacit and Explicit Knowledge were originally calibrated as a single fuzzy-set condition. However, doing so meant that participants' responses were inaccurately reflected because responses referring to both knowledge types could not be recorded on the aforementioned single continuum. Thus, it was deemed necessary to divide knowledge type into two sets: either tacit or explicit. In this manner, membership in "tacit knowledge" could 
be coded as 1 , a crossover point as 0.5, and non-membership as 0. Explicit knowledge was recoded in the same manner. The combination of explicit and tacit knowledge was indicated by representing membership in each condition in the analysis. The nature of these conditions meant that applying a 3-value fuzzy set was more suitable to capture participants' responses representatively.

Following calibration, the fsQCA software produces a truth table, which requires refinement according to the criteria of frequency and consistency. Frequency refers to the number of empirical observations of cases containing each specific combination of causal conditions. For a small data set, an acceptable frequency cutoff can be set at 1 (Ragin, 2009). Consistency reflects the degree to which the causal combinations represent a subset of the outcome (Ragin, 2009). The minimum acceptable consistency threshold for any solution is recommended as 0.75 (Ragin, 2006). Configurations with a frequency value of less than 1 and a consistency value of less than 0.8 were consequently removed from the truth table.

\section{Results and discussion}

The fsQCA results offer three types of solutions that contain the presence or absence of different conditions but ultimately lead to the same outcome: knowledge transfer success. The two solutions that are recommended for further discussion are the parsimonious and intermediate solutions (Fiss, 2011) because they incorporate logical remainders (configurations with no empirical evidence). Causal conditions that are present in both the parsimonious solution and the intermediate solution are referred to as core conditions; those that are solely present in the intermediate solution are peripheral conditions. Observing which conditions are present in either solution determines the causal essentiality of the conditions (Fiss, 2011). Core conditions are deemed essential, whereas peripheral conditions can be 
considered of lesser importance because of their exchangeability with other conditions (Fiss, 2011).

\subsection{Solutions for coopetitive partnerships}

Table 2 displays the core and peripheral conditions that are present for the coopetitive partnership category.

Insert Table 2 here.

The results for the coopetitive category give four solutions for knowledge transfer success. Solution 1 combines the presence of Explicit Knowledge, Low Causal Ambiguity, Trust, Tie Strength, Learning Intent, and Absorptive Capacity with the absence of Tacit Knowledge and Cultural Similarity; Understanding is considered a redundant condition. The absence of Tacit Knowledge is a core condition here. Solutions 2 and 3 both combine the presence of Tacit Knowledge, Explicit Knowledge, Understanding, Low Causal Ambiguity, Tie Strength, Cultural Similarity, and Learning Intent. They differ in the redundancy of Absorptive Capacity in Solution 2 and Trust in Solution 3. Core conditions in both solutions are the presence of Cultural Similarity and Learning Intent. Solution 4 combines the presence of Tacit and Explicit Knowledge, Low Causal Ambiguity, Tie Strength, Cultural Similarity, and Learning Intent with the absence of Understanding, Trust, and Absorptive Capacity. Core conditions here are Cultural Similarity and Learning Intent.

The sole core condition in Solution 1 is the absence of Tacit Knowledge; all other conditions are peripheral. Knowledge that has an explicit quality is thus of greater importance in this solution for generating a successful transfer process. The literature states that explicit knowledge is more readily transferred than tacit knowledge (Nonaka \& Takeuchi, 1995; Spender, 1996; Wang \& Wang, 2012), implying that tacit knowledge may delay the transfer process. Loebecke, Van Fenema, and Powell (1999) argue that knowledge tacitness hinders the dynamics of knowledge exchange in coopetitive relationships. Participants stated that the 
transferred knowledge commonly comprised "logistical aspects of the process" rather than experiential information (Director, Multinational Telecommunications Enterprise). The absence of Tacit Knowledge was further reiterated by the fact that the knowledge exchanged was more "formalized knowledge surrounding key technologies" (Coordinator, Multinational Transport Enterprise). This finding indicates that knowledge transfer success in Solution 1 is highly dependent on this absence of Tacit Knowledge. As reflected by participant responses, the fundamental goal of a coopetitive partnership relates to the exchange of information regarding specific technologies for innovative purposes. Competitive partners may wish to share solely explicit information to avoid disclosure of the more idiosyncratic knowledge surrounding experiences specific to their own organization, which could be more valuable with a view to imitation. Accordingly, the absence of Tacit Knowledge is a core condition for knowledge transfer success between multinational organizations. This finding contradicts previous findings that indicate the importance of tacit knowledge exchange for coopetition (Bouncken \& Kraus, 2013; Estrada, Faems, \& de Faria, 2016; Ho \& Ganesan, 2013); instead, the absence of this condition results in knowledge transfer success, indicating that its explicit counterpart is of greater importance for achieving this outcome.

Core conditions in Solutions 2, 3, and 4 are the presence of Cultural Similarity and Learning Intent, expressed as Cultfz*Learnfz, where “*” denotes the combination of two conditions. This finding indicates that the presence of both of these conditions has a strong causal relationship with the outcome. Participants stated that their culture was "highly similar" (Director, Small Technology Business) to their ecosystem partner's, and their cultural similarity with this partner was argued to generate "greater consistency and alignment of ideas" (Department Head, Multinational Services Enterprise) when collaborating with a competitor. This cultural similarity helped facilitate an "understanding of how they operate," making the competitor "more appealing as an engagement partner" 
(Manager, Multinational Consultancy Enterprise). Such goal alignment and common vision have previously been cited as critical success factors for coopetition (Planko et al., 2019). Cultural similarity is therefore perceived to encourage competitors to co-create and to facilitate and maintain partnerships. The presence of Cultural Similarity across $75 \%$ of the solutions is to be expected: competitive partners often have greater cultural congruency because they are similar in size and scale, often residing in the same industry. Indeed, such similarities are what makes them competitors.

The combination of Cultfz*Learnfz in this solution arguably arises because participants identified Learning Intent as a "requirement for co-creation" (Director, Small Software Business). Cultural consistency between organizations could thus create a desire and intent to learn from a partner organization. This finding supports Lawson and Potter's (2012) claim that an organization is encouraged to transfer knowledge if collaborating with a partner that perpetuates a desire to receive that knowledge. Such a desire is arguably embedded in the norms and values of an organization and is subsequently integrated into its overall culture. Thus, having similar cultures can act as an antecedent for Learning Intent, explaining the presence of these two conditions as a core configuration across Solutions 2, 3, and 4.

\subsubsection{Necessary conditions}

When assessing the presence of necessary conditions in a data set, consistency scores of 0.9 or higher are recommended (Ragin, 2009). The closer the consistency score is to 1 , the greater the extent to which the condition leads to the outcome. In the coopetitive category, three conditions surpass the recommended consistency threshold: Explicit Knowledge (0.98), Tie Strength (0.98), and Learning Intent (0.90). 
Explicit Knowledge. The presence of Explicit Knowledge as a necessary condition arguably derives from the nature of coopetitive partnerships. Generally, organizations seek to collaborate with potential competitors within their ecosystem for the common purpose of addressing a shared problem (Nieto \& Santamaría, 2007). Consequently, the knowledge exchanged with ecosystem partners is typically "technical information" (Director, Multinational Telecommunications Enterprise). The ease of transfer associated with explicit knowledge (Nonaka \& Takeuchi, 1995; Spender, 1996; Wang \& Wang, 2012) and its ability to facilitate interfirm learning in coopetitive partnerships (Bouncken \& Kraus, 2013) arguably explains its presence across all solutions; in the coopetitive category, the exchange of highly specific knowledge with regard to an identified innovation requirement comprises the fundamental motive for engaging in the partnership.

Tie Strength. Tie Strength exists as a necessary condition across all solutions. Participants stated that they had "well-established" relationships (Director, Multinational Telecommunications Enterprise) with "strong qualities" (Director, Small Technology Business) that "[elevated] the relationship" (Department Head, Multinational Service Enterprise). Participants even specified that "possessing a weak relationship can lead to the diminution of a relationship where the partner will leave" (Department Head, Multinational Technology Enterprise). Additionally, the difficulties associated with engaging with a competitor and the associated erosion of trust mean that a strong relationship can often formulate the backbone of the partnership and can be a source of reliance where trust is potentially being diminished. The literature cites the importance of strong ties in facilitating coopetition (Brolos, 2009; Choi, Garcia, \& Friedrich, 2009). The presence of Tie Strength as a necessary condition in this data set substantiates this claim.

Learning Intent. The presence of Learning Intent as an additional core condition in this category arguably arises because "a willingness and ability to innovate" was cited as 
fundamental for engaging in an ecosystem partnership (Department Head, Multinational Technology Enterprise). Participants expressed that their organizations fostered " $a$ culture of enjoying learning and seeing value from it" (Director, Multinational Telecommunications Enterprise) and demonstrated this importance by ensuring that it was "embedded in strategy" (Director, Small Consultancy Business). The literature also states that a fundamental aim of a competitive partnership is to learn about the potential competencies of competitors (Hamel, Doz, \& Prahalad, 1989). Research further accentuates the importance of learning intent for knowledge transfer success (Bandyopadhyay \& Pathak, 2007; Inkpen, 1998; Tsang, 2002), with further studies postulating the ability of learning intent to offer increased opportunities to foster coopetitive benefits (Ho \& Ganesan, 2012). Thus, the empirical and theoretical evidence reinforces the importance of Learning Intent for coopetition in knowledge sharing contexts, supporting its presence as a necessary condition.

The four solutions for the coopetitive category can be considered informative, with consistency values higher than 0.74 and coverage values between 0.25 and 0.90 (Oyemomi, Liu, Neaga, \& Alkhuraiji, 2016). These values support the authenticity of the solutions. Overall consistency is high, nearly reaching perfect consistency (Ragin, 2006). Overall solution coverage indicates that the causal configurations account for a large proportion of the instances of the outcome (Ragin, 2009).

The results for the coopetitive category confirm the combinatory nature of the knowledge transfer characteristics. While Cultural Similarity and Learning Intent are core conditions, absorptive capacity fails to display the same level of importance. Thus, firmspecific characteristics cannot be considered more important for this category. Interestingly, the analysis reveals one condition from each characteristic as necessary, strengthening the implication of each condition grouping for knowledge transfer success. For coopetitive 
partnerships, knowledge-, firm-, and relationship-level characteristics form configurational associations for successful knowledge transfer.

\subsection{Solutions for non-competitive partnerships}

Table 3 shows the solutions for non-competitive partnerships.

Insert Table 3 here.

The results for the non-competitive category reveal different solutions for knowledge transfer success from those for the coopetitive category. Solution 1 combines the presence of Tacit Knowledge, Explicit Knowledge, Understanding, Trust, Tie Strength, and Learning Intent with the absence of Low Causal Ambiguity and Absorptive Capacity; Cultural Similarity is considered a redundant condition. Core conditions here are Explicit Knowledge and Learning Intent. Solution 2 combines the presence of all conditions aside from Cultural Similarity, an absent condition, and Absorptive Capacity, a redundant condition. Core conditions in Solution 2 are Explicit Knowledge and Learning Intent. Solution 3 combines the presence of Tacit Knowledge, Low Causal Ambiguity, and Tie Strength with the absence of Explicit Knowledge, Understanding, Trust, Cultural Similarity, Learning Intent and Absorptive Capacity. The absence of Cultural Similarity and the absence of Absorptive Capacity are both core conditions. Solution 4 combines the presence of Tacit and Explicit Knowledge, Understanding, Low Causal Ambiguity, and Learning Intent, with the absence of Trust, Tie Strength, Cultural Similarity and Absorptive Capacity. Core conditions in Solution 4 are Explicit Knowledge and Learning Intent.

Solution 3 contains the causal configuration $\sim$ Cultfz* $\sim$ Acapfz, where " $\sim$ " denotes the absence of the condition. This combination is core in this solution, perhaps because noncompetitive partnerships are sought for different reasons than those for which coopetitive partnerships are sought. Whereas coopetition is pursued to address knowledge gaps in a 
specific domain (Yami \& Nemeh, 2014) or to carry out research and establish standards (Gueguen, 2009; Tether, 2002), sole collaboration may be pursued for the purposes of differentiation. As indicated by one participant, innovation partners can "offer different ways of working" (Director, Small Consultancy Business). These inconsistencies between working practices may indicate that a lack of cultural similarity between organizations is beneficial for successful knowledge transfer. The combination $\sim$ Cultfz* $\sim$ Acapfz confirms the theoretical connections found in the literature: research states that the extent of an organization's absorptive capacity derives from cultural compatibility between partners (Lane, Salk, \& Lyles, 2001; Martinkenaite, 2011). Participants identified an organizational commitment to absorb knowledge but an overall "reluctance to do so in practice" (Business Development Officer, Small Technology Business). Additionally, participants cited absorptive capacity as a "challenge for the organization" because of the "fast-paced growth of the industry and the organization itself," which presented difficulties in terms of "struggling with the basics" (Director, Small Consultancy Business). Nonetheless, the absence of Absorptive Capacity appears to facilitate successful knowledge transfer when combined with the absence of Cultural Similarity. A lack of cultural consistency between organizations may therefore discourage internal dissemination of the transferred knowledge within the recipient organization; however, this lack of cultural consistency does not affect knowledge transfer success.

In Solutions 1, 2, and 4, the causal configuration Learnfz*Expfz is core for knowledge transfer success. Research suggests that the process of organizational learning requires an overall intent to learn (Evangelista, 2007; Hamel, 1991; Mohr \& Sengupta, 2002). Participants stated that their organizations were "always open to learning new ideas" (Chief Financial Officer, Small Financial Business). Like in the coopetitive category, participants stressed the importance of learning intent, deeming it "necessary for survival" (Director, 
Small Consultancy Business; Director, Small Software Business). The combination Learnfz*Expfz emphasizes that participants are more likely to learn from an innovation partner if the partner provides the required knowledge type.

\subsubsection{Necessary conditions}

The core condition Expfz is present in three out of the four solutions. Interestingly, Explicit Knowledge is a necessary condition for the coopetitive category. Conversely, Tacit Knowledge has a consistency score of 0.97 in the analysis of necessary conditions for this category. Its presence across all four solutions further supports the necessity of this condition.

When exploring scale responses from participants in this category, all responses indicate the presence of either Tacit Knowledge alone or in conjunction with Explicit Knowledge. Participants expressed that the knowledge transferred included "technical information" as well as sharing "pockets of expertise" combined with "personal experiences" (Manager, Small Technology Business). Knowledge was argued to be explicit in terms of retaining "market-specific" qualities that were primarily "technology and solution based" and tacit in terms of "experience and information... more informal, best practices, dos and don'ts" (Director, Small Technology Business). Interestingly, participants believed that the stage of the innovation process influenced the type of knowledge exchanged, but there seemed to be discord between participants. Some participants perceived tacit knowledge exchange to occur initially to create a sense of "personal alignment" and "[understanding] of people," which is "necessary for business development" (Manager, Small Technology Business). Evolution of the partnership arguably supports the exchange of more explicit knowledge because tacit knowledge needs to be present to "facilitate understanding and create the relationship" (Manager, Small Technology Business). In contrast, some participants stated that "technology exchange occurred on the outset" and then evolved into 
experiential information pertaining to the achievement of "performance and results" (Chief Financial Officer, Small Financial Business). It thus seems that knowledge type has greater fluidity in the context of non-competitive ecosystem partnerships. This greater fluidity may derive from the fact that coopetitive partnerships perpetuate a more superficial knowledge transfer process, occurring at surface level to eradicate the potential exploitation or imitation of the knowledge that is transferred. Non-competitive partnerships maintain a more complex relationship in terms of knowledge, retaining more flexible qualities that are subject to change over the course of the partnership.

Overall solution coverage and consistency values are similar to the values for the coopetitive category ( 0.75 and 0.93 , respectively), implying that all solutions are informative. Because these scores are almost the same for the two partnership types, their comparability is high. No condition grouping demonstrates sufficiency or necessity, again confirming that combinations of condition characteristics are responsible for success. This conclusion is further reinforced by the observation that cross-category conditions act as causal configurations (e.g., Learnfz*Expfz). Hence, conditions exert a combinatory effect on the occurrence of success.

\section{Conclusions}

This study establishes considerable distinctions between coopetitive versus noncompetitive partnerships operating in open innovation ecosystems. To capture the heterogeneity in these partnership types, fsQCA was employed to conduct a configurational analysis of knowledge transfer conditions and detect their combinations in the form of causal recipes. The findings reveal that although individual conditions are necessary across partnership types, the success of both coopetitive and non-competitive partnerships ultimately depends on combinations of knowledge-, firm-, and relationship-related characteristics. No 
solution exceeded the acceptable consistency threshold (0.75) for the absence of the outcome. Thus, although certain conditions are associated with the presence of success, further research is required to detect the antecedents of the absence of success.

\subsection{Theoretical implications}

This study has major theoretical implications for coopetition research. Existing literature has explored the link between coopetition and innovation (Bouncken \& Kraus, 2013; Gnyawali \& Park, 2011; Leitão \& Pereira, 2015; Ribeiro-Soriano et al., 2016; Ritala \& Hurmelinna-Laukkanen, 2013; Ritala et al., 2016; Yami \& Nemeh, 2014). However, in terms of ecosystems, business ecosystems remain the predominant focus of such studies (Gueguen, 2009; Gueguen \& Isckia, 2011; Ritala et al., 2014), with few studies addressing this link by shifting the focus to coopetition in open innovation ecosystems. This research thus contributes to the coopetition literature by empirically analyzing the construct in open innovation ecosystem contexts.

This research also extends coopetition research by presenting a comparative analysis of coopetitive versus non-competitive partnerships. Notable studies evaluating coopetition in ecosystem contexts have typically relied on absolute analyses, solely examining coopetition itself (Ansari et al., 2016; Basole et al., 2015; Gueguen, 2009; Gueguen \& Isckia, 2011; Ritala et al., 2013; Ritala et al., 2014; Selander et al., 2010). They have thus failed to ascertain how coopetitive mechanisms differ from non-competitive mechanisms. In addressing this absence, this study compares various configurations of knowledge transfer success for coopetitive and non-competitive partners, thus providing a more comprehensive examination of how success is affected by the competitive nature of ecosystem partnerships.

The elucidation of the differences between these partnerships, achieved using configurational approaches, is a further contribution of this research, whereby the application 
of fsQCA has accentuated fundamental distinctions between coopetitive and non-competitive ecosystem partners. The application of fsQCA in innovation-related research is becoming more common (see Kraus, Ribeiro-Soriano, \& Schüssler, 2018), and fsQCA is an established methodological tool for coopetition studies (Adame-Sánchez, Caplliure, \& Miquel-Romero, 2018; Bouncken, Fredrich, \& Kraus, 2019; Fredrich et al., 2019; Ribeiro-Soriano et al., 2016). In response to Ritala et al.'s (2016) recommendation to analyze coopetition through novel methods such as fsQCA, this paper is, to the best of our knowledge, one of the first to use fsQCA to compare the causal configurations of coopetitive and non-competitive relationship types in the context of innovation ecosystems. This research thus further contributes to a growing body of research that applies configurational approaches to innovation-related outcomes.

\subsection{Practical implications}

The findings of this research have noteworthy implications for practitioners engaging in open coopetitive partnerships in innovation ecosystems. Equifinal causal configurations, combined with the lack of sufficient conditions in this data set, reflect the absence of a single model of best-fit for knowledge transfer success. Instead, success remains context-bound and depends on the nature of the partnership. Although a unifying approach is lacking, this study does identify the prominent role of necessary conditions for both coopetitive and noncompetitive partnerships. For coopetitive partnerships, explicit knowledge, tie strength, and learning intent are necessary. Firms should thus introduce mechanisms to encourage the presence of these conditions in their partnerships. First, establishing measures for strengthening interfirm partnerships through, for example, increased interactions (RejebKhachlouf, Mezghani, \& Quélin, 2011) could be beneficial in contexts where weaknesses in interfirm relations are observed. Organizations could thus increase opportunities to interact 
with partners (e.g., meetings, workshops, and visits) to foster stronger partnerships. To elicit the exchange of explicit knowledge, organizations could increase transparency in the information exchanged and attempt to disentangle any personalized or experiential components. Doing so would ensure that the information exchanged was solely explicit, thus increasing the likelihood of successful transfer when partnering with competitors. Finally, the emergence of learning intent as a necessary (and core) condition implies that corporations should encourage employees to be motivated to learn from partners, in turn increasing the learning intent of the organization as a whole.

This study further highlights the necessity of tacit knowledge in non-competitive ecosystem partnerships. Previous research has offered measures to accelerate tacit knowledge transfer, namely having increased interaction (Inkpen \& Dinur, 1998), building strong relationships based on trust (Mu, Love, \& Peng, 2008; Panteli \& Sockalingam, 2005; Roberts, 2000), and establishing a common language (Carlile, 2004). Firms could use such mechanisms as a basis for encouraging tacit knowledge transfer by increasing opportunities to interact with partners, thereby creating and strengthening trust in the partnership.

Lastly, this research shows the prominence of learning intent as a core condition across both partnership types. Organizations should therefore incorporate learning intent in their business strategies and communicate its importance to ensure that information is exchanged successfully across the ecosystem. Identifying this commonality across both partnership types can mitigate the absence of a consistent approach to knowledge transfer success. In general, firms should be mindful of the idiosyncrasies of coopetitive versus noncompetitive partnerships and the different routes to successful knowledge transfer in each case. Innovation approaches should therefore be tailored specifically to the partnership type. The heterogeneity of knowledge transfer practices makes it difficult for organizations to ensure that knowledge transfer is accomplished. Ultimately, awareness of which conditions 
are most important in the context of coopetition and which combinations of conditions contribute to success in these instances should help practitioners ensure that information is successfully exchanged with their ecosystem partners.

\subsection{Limitations}

As with all research, a number of limitations apply to this study and could be alleviated through further research. First, no solutions surpassed the consistency threshold for the absence of the outcome. Hence, further research is required to identify the conditions associated with the absence of success. Second, the sample of 20 respondents was relatively small. Although fsQCA has been identified as particularly suitable for small-N data sets (Woodside, 2013), the generalizability of the results is questionable. Future research could address this limitation through similar analyses on a wider scale using a larger sample of respondents. Additionally, the small sample size results in a limited empirical investigation on a range of industries, organization types, organizational positions, and innovative developments, all of which could shape the samples and contexts of future studies. 


\section{References}

Adame-Sánchez, C., Caplliure, E. M., \& Miquel-Romero, M. J. (2018). Paving the way for coopetition: drivers for work-life balance policy implementation. Review of Managerial Science, 12(2), 519-533. doi.org/10.1007/s11846-017-0271-y

Al-Salti, Z., \& Hackney, R. (2011). Factors impacting knowledge transfer success in information systems outsourcing. Journal of Enterprise Information Management, 24(5), 455-468. doi.org/10.1108/17410391111166521

Ansari, S., Garud, R., \& Kumaraswamy, A. (2016). The disruptor's dilemma: TiVo and the US television ecosystem. Strategic Management Journal, 37(9), 1829-1853. doi.org/10.1002/smj.2442

Bacon, E., Williams, M. D., \& Davies, G. H. (2019). Recipes for success: Conditions for knowledge transfer across open innovation ecosystems. International Journal of Information Management, 49, 377-387. doi.org/10.1016/j.ijinfomgt.2019.07.012

Baierl, R., Anokhin, S., \& Grichnik, D. (2016). Coopetition in corporate venture capital: the relationship between network attributes, corporate innovativeness, and financial performance. International Journal of Technology Management, 71(1-2), 58-80. doi.org/10.1504/ijtm.2016.077978

Bandyopadhyay, S., \& Pathak, P. (2007). Knowledge sharing and cooperation in outsourcing projects-A game theoretic analysis. Decision Support Systems, 43(2), 349-358. doi.org/10.1016/j.dss.2006.10.006

Basole, R. C., Park, H., \& Barnett, B. C. (2015). Coopetition and convergence in the ICT ecosystem. Telecommunications Policy, 39(7), 537-552.

doi.org/10.1016/j.telpol.2014.04.003 
Baumard, P. (2009). An asymmetric perspective on coopetitive strategies. International Journal of Entrepreneurship and Small Business, 8(1), 6-22.

doi.org/10.1504/IJESB.2009.024102

Bengtsson, M., \& Kock, S. (2000). "Coopetition" in business networks - to cooperate and compete simultaneously. Industrial Marketing Management, 29(5), 411-426. doi.org/10.1016/s0019-8501(99)00067-x

Bengtsson, M., \& Kock, S. (2014). Coopetition-Quo vadis? Past accomplishments and future challenges. Industrial Marketing Management, 43(2), 180-188. doi.org/10.1016/j.indmarman.2014.02.015

Bengtsson, M., \& Raza-Ullah, T. (2016). A systematic review of research on coopetition: Toward a multilevel understanding. Industrial Marketing Management, 57, 23-39. doi.org/10.1016/j.indmarman.2016.05.003

Bengtsson, M., Raza-Ullah, T., \& Vanyushyn, V. (2016). The coopetition paradox and tension: The moderating role of coopetition capability. Industrial Marketing Management, 53, 19-30. doi.org/10.1016/j.indmarman.2015.11.008

Bogers, M., Chesbrough, H., \& Moedas, C. (2018). Open innovation: research, practices, and policies. California Management Review, 60(2), 5-16. doi.org/10.1177/0008125617745086

Bougrain, F., \& Haudeville, B. (2002). Innovation, collaboration and SMEs internal research capacities. Research Policy, 31(5), 735-747. doi.org/10.1016/S00487333(01)00144-5

Bouncken, R. B., \& Kraus, S. (2013). Innovation in knowledge-intensive industries: The double-edged sword of coopetition. Journal of Business Research, 66(10), 2060-2070. doi.org/10.1016/j.jbusres.2013. 02.032

Bouncken, R. B., Fredrich, V., \& Kraus, S. (2019). Configurations of firm-level value capture in coopetition. Long Range Planning. doi.org/10.1016/j.lrp.2019.02.002 
Bouncken, R. B., Gast, J., Kraus, S., \& Bogers, M. (2015). Coopetition: A systematic review, synthesis, and future research directions. Review of Managerial Science, 9(3), 577601. doi.org/10.1007/s11846-015-0168-6

Brolos, A. (2009). Innovative coopetition: the strength of strong ties. International Journal of Entrepreneurship and Small Business, 8(1), 110-134. doi.org/10.1504/ijesb.2009.024108

Carayannis, E. G., \& Campbell, D. F. (2009). 'Mode 3' and 'Quadruple Helix': Toward a 21st century fractal innovation ecosystem. International Journal of Technology Management, 46(3-4), 201-234. doi.org/10.1504/ijtm.2009.023374

Carlile, P. R. (2004). Transferring, translating, and transforming: An integrative framework for managing knowledge across boundaries. Organization Science, 15(5), 555-568. doi.org/10.1287/orsc. 1040.0094

Charleton, T. R., Gnyawali, D. R., \& Galavan, R. J. (2018). Theoretical perspectives of coopetition: Review and integration. In A. S. Fernandez, P. Chiambaretto, F. Le Roy, \& W. Czakon, (Eds.), Routledge Companion to Coopetition Strategies (pp. 45-47). New York City, NY: Routledge.

Chesbrough, H. (2003) Open innovation: The new imperative for creating and profiting from technology. Boston, MA: Harvard Business School Press.

Chin, K. S., Chan, B. L., \& Lam, P. K. (2008). Identifying and prioritizing critical success factors for coopetition strategy. Industrial Management \& Data Systems, 108(4), 437454. doi.org/10.1108/02635570810868326

Choi, P., Garcia, R., \& Friedrich, C. (2009). The drivers for collective horizontal coopetition: A case study of screwcap initiatives in the international wine industry. International Journal of Strategic Business Alliances, 1(3), 271-290.

doi.org/10.1504/ijsba.2010.030427 
Chua, A. (2003). Knowledge sharing: a game people play. Aslib Proceedings: New Information Perspectives, 55, 3, 117-129.

Cohen, W. M., \& Levinthal, D. A. (1990). Absorptive capacity: A new perspective on learning and innovation. Administrative Science Quarterly, 35(1), 128-152. doi.org/10.2307/2393553

Czachon, W., \& Mucha-Kuś, K. (2014). Coopetition research landscape - a systematic literature review 1997-2010. Journal of Economics \& Management, 17, 122-150.

Devece, C., Ribeiro-Soriano, D. E., \& Palacios-Marqués, D. (2019). Coopetition as the new trend in inter-firm alliances: Literature review and research patterns. Review of Managerial Science, 13(2), 207-226. doi.org/10.1007/s11846-017-0245-0

Dorn, S., Schweiger, B., \& Albers, S. (2016). Levels, phases and themes of coopetition: A systematic literature review and research agenda. European Management Journal, 34(5), 484-500. doi.org/10.1016/j.emj.2016.02.009

Easterby-Smith, M., Lyles, M. A., \& Tsang, E. W. (2008). Inter-organizational knowledge transfer: Current themes and future prospects. Journal of Management Studies, 45(4), 677-690. doi.org/10.1111/j.1467-6486.2008.00773.x

Enkel, E., Gassmann, O., \& Chesbrough, H. (2009). Open R\&D and open innovation: Exploring the phenomenon. $R \& d$ Management, 39(4), 311-316. doi.org/10.1111/j.1467-9310.2009.00570.x

Estrada, I., Faems, D., \& de Faria, P. (2016). Coopetition and product innovation performance: The role of internal knowledge sharing mechanisms and formal knowledge protection mechanisms. Industrial Marketing Management, 53, 56-65. doi.org/10.1016/j.indmarman.2015.11.013 
Evangelista, F. (2007). Acquiring tacit and explicit marketing knowledge from foreign partners in IJVs. Journal of Business Research, 60(11), 1152-1165. doi.org/10.1016/j.jbusres.2007.04.006

Fernandez, A. S., Chiambaretto, P., Le Roy, F., \& Czakon, W. (2018). Routledge Companion to Coopetition Strategies. New York City, NY: Routledge.

Fiss, P. C. (2011). Building better causal theories: A fuzzy set approach to typologies in organization research. Academy of Management Journal, 54(2), 393-420. doi.org/10.5465/amj.2011.60263120

Fredrich, V., Bouncken, R. B., \& Kraus, S. (2019). The race is on: Configurations of absorptive capacity, interdependence and slack resources for interorganizational learning in coopetition alliances. Journal of Business Research, 101, 862-868. doi.org/10.1016/j.jbusres.2018.11.038

Gast, J., Filser, M., Gundolf, K., \& Kraus, S. (2015). Coopetition research: Towards a better understanding of past trends and future directions. International Journal of Entrepreneurship and Small Business, 24(4), 492-521. doi.org/10.1504/ijesb.2015.068637

Gnyawali, D. R., \& Charleton, T. R. (2018). nuances in the interplay of competition and cooperation: Towards a theory of coopetition. Journal of Management, 44(7), 25112534. doi.org/10.1177/0149206318788945

Gnyawali, D. R., \& Park, B. J. (2009). Co-opetition and technological innovation in small and medium-sized enterprises: A multilevel conceptual model. Journal of Small Business Management, 47(3), 308-330. doi.org/10.1111/j.1540-627x.2009.00273.x

Gnyawali, D. R., \& Park, B. J. (2011). Co-opetition between giants: Collaboration with competitors for technological innovation. Research Policy, 40(5), 650-663. doi.org/10.1016/j.respol.2011.01.009 
Goodman, L. A. (1961). Snowball sampling. The Annals of Mathematical Statistics, 32(1), 148-170. doi.org/10.1214/aoms/1177705148

Greckhamer, T., Misangyi, V. F., Elms, H., \& Lacey, R. (2008). Using qualitative comparative analysis in strategic management research: An examination of combinations of industry, corporate, and business-unit effects. Organizational Research Methods, 11(4), 695-726. doi.org/10.1177/1094428107302907

Gueguen, G. (2009). Coopetition and business ecosystems in the information technology sector: the example of Intelligent Mobile Terminals. International Journal of Entrepreneurship and Small Business, 8(1), 135-153.

doi.org/10.1504/IJESB.2009.024109

Gueguen, G., \& Isckia, T. (2011). The borders of mobile handset ecosystems: Is coopetition inevitable? Telematics and Informatics, 28(1), 5-11. doi.org/10.1016/j.tele.2010.05.007

Hamel, G. (1991). Competition for competence and interpartner learning within international strategic alliances. Strategic Management Journal, 12(S1), 83-103. doi.org/10.1002/smj.4250120908

Hamel, G., Doz, Y. L., \& Prahalad, C. K. (1989). Collaborate with your competitors and win. Harvard Business Review, 67(1), 133-139.

Harbison, J. R., \& Pekar Jr., P. (1998). Smart alliances: A practical guide to repeatable success (Vol. 2). San Francisco, CA: Jossey-Bass.

Ho, H. D., \& Ganesan, S. (2012). Learning in coopetitive relationships. In G. Lilien \& R. Grewal (Eds.), Handbook on Business to Business Marketing (pp. 368-385), Cheltenham, UK: Edward Elgar Publishing. 
Ho, H. D., \& Ganesan, S. (2013). Does knowledge base compatibility help or hurt knowledge sharing between suppliers in coopetition? The role of customer participation. Journal of Marketing, 77(6), 91-107. doi.org/10.1509/jm.11.0570

Inkpen, A. C. (1998). Learning and knowledge acquisition through international strategic alliances. Academy of Management Perspectives, 12(4), 69-80. doi.org/10.5465/ame.1998.1333953

Inkpen, A. C., \& Dinur, A. (1998). Knowledge management processes and international joint ventures. Organization Science, 9(4), 454-468. doi.org/10.1287/orsc.9.4.454

Kraus, S., Ribeiro-Soriano, D., \& Schüssler, M. (2018). Fuzzy-set qualitative comparative analysis (fsQCA) in entrepreneurship and innovation research-the rise of a method. International Entrepreneurship and Management Journal, 14(1), 15-33. doi.org/10.1007/s11365-017-0461-8

Lane, P. J., Salk, J. E. \& Lyles, M. A. (2001). Absorptive capacity, learning, and performance in international joint ventures. Strategic Management Journal, 22(12), 1139-61. doi.org/10.1002/smj.206

Lawson, B., \& Potter, A. (2012). Determinants of knowledge transfer in inter-firm new product development projects. International Journal of Operations \& Production Management, 32(10), 1228-1247. doi.org/10.1108/01443571211274530

Leitão, J., \& Pereira, D. (2015). Absorptive capacity, coopetition and product innovation: A comparative analysis between Italian and Portuguese service firms. International Conference on Industrial Engineering and Systems Management, Seville, 1121-1135. doi.org/10.1109/IESM.2015.7380295

Loebecke, C., Van Fenema, P. C. \& Powell, P. (1999). Co-opetition and knowledge transfer. Advances in Information Systems, 30, 2, 14-25. doi.org/10.1145/383371.383373 
Martinkenaite, I. (2011). Antecedents and consequences of inter-organizational knowledge transfer: Emerging themes and openings for further research. Baltic Journal of Management, 6(1), 53-70. doi.org/10.1108/17465261111100888

Mazloomi Khamseh, H., \& Jolly, D. R. (2008). Knowledge transfer in alliances: determinant factors. Journal of Knowledge Management, 12(1), 37-50. doi.org/10.1108/13673270810852377

Mohr, J. J., \& Sengupta, S. (2002). Managing the paradox of inter-firm learning: The role of governance mechanisms. The Journal of Business \& Industrial Marketing, 17(4), 282301. doi.org/10.1108/08858620210431688

Mowery, D. C., Oxley, J. E., \& Silverman, B. S. (1996). Strategic alliances and interfirm knowledge transfer. Strategic Management Journal, 17(S2), 77-91. doi.org/10.1002/smj.4250171108

Mu, J., Love, E., \& Peng, G. (2008). Interfirm networks, social capital, and knowledge flow. Journal of Knowledge Management, 12(4), 86-100. doi.org/10.1108/13673270810884273

Narteh, B. (2008). Knowledge transfer in developed-developing country interfirm collaborations: a conceptual framework. Journal of Knowledge Management, 12(1), 78-91. doi.org/10.1108/13673270810852403

Nieto, M. J., \& Santamaría, L. (2007). The importance of diverse collaborative networks for the novelty of product innovation. Technovation, 27(6-7), 367-377. doi.org/10.1016/j.technovation.2006.10.001

Nonaka, I. \& Takeuchi, H. (1995). The Knowledge Creating Company. Oxford, UK: Oxford University Press.

Ordanini, A., Parasuraman, A., \& Rubera, G. (2014). When the recipe is more important than the ingredients: A qualitative comparative analysis (QCA) of service innovation 
configurations. Journal of Service Research, 17(2), 134-149. doi.org/10.1177/1094670513513337

Osgood, C. E., Suci, G. J., \& Tannenbaum, P. H. (1957). The measurement of meaning. Champaign, IL: University of Illinois Press.

Oxley, J. E., \& Sampson, R. C. (2004). The scope and governance of international R\&D alliances. Strategic Management Journal, 25(8-9), 723-749. doi.org/10.1002/smj.391

Oyemomi, O., Liu, S., Neaga, I., \& Alkhuraiji, A. (2016). How knowledge sharing and business process contribute to organizational performance: Using the fsQCA approach. Journal of Business Research, 69(11), 5222-5227. doi.org/10.1016/j.jbusres.2016.04.116

Panteli, N., \& Sockalingam, S. (2005). Trust and conflict within virtual inter-organizational alliances: A framework for facilitating knowledge sharing. Decision Support Systems, 39(4), 599-617. doi.org/10.1016/j.dss.2004.03.003

Pappas, I. O., Kourouthanassis, P. E., Giannakos, M. N., \& Chrissikopoulos, V. (2016). Explaining online shopping behavior with fsQCA: The role of cognitive and affective perceptions. Journal of Business Research, 69(2), 794-803. doi.org/10.1016/j.jbusres.2015.07.010

Pettigrew, A. (1990). Longitudinal field research on change: Theory and practice. Organization Science, 1, 267-292. doi.org/10.1287/orsc.1.3.267

Planko, J., Chappin, M. M., Cramer, J., \& Hekkert, M. P. (2019). Coping with coopetitionFacing dilemmas in cooperation for sustainable development: The case of the Dutch smart grid industry. Business Strategy and the Environment, 28(5), 665-674. doi.org/10.1002/bse.2271 
Prashantham, S., \& Birkinshaw, J. (2008). Dancing with gorillas: How small companies can partner effectively with MNCs. California Management Review, 51(1), 6-23. doi.org/10.2307/41166466

Ragin, C. C. (2006). Set relations in social research: Evaluating their consistency and coverage. Political Analysis, 14(3), 291-310. doi.org/10.1093/pan/mpj019

Ragin, C. C. (2009). Redesigning social inquiry: Fuzzy sets and beyond. Chicago, IL: University of Chicago Press.

Rejeb-Khachlouf, N., Mezghani, L., \& Quélin, B. (2011). Personal networks and knowledge transfer in inter-organizational networks. Journal of Small Business and Enterprise Development, 18(2), 278-297. doi.org/10.1108/14626001111127070

Ribeiro-Soriano, D. E., Roig-Tierno, N., \& Mas-Tur, A. (2016). Governance models of coopetition and innovation: The case of Spanish firms. International Journal of Technology Management, 71(1-2), 38-57. doi.org/10.1504/ijtm.2016.077977

Ritala, P., \& Hurmelinna-Laukkanen, P. (2009). What's in it for me? Creating and appropriating value in innovation related coopetition. Technovation, 29(12), 819-828. doi.org/10.1016/j.technovation.2009.07.002

Ritala, P., \& Hurmelinna-Laukkanen, P. (2013). Incremental and radical innovation in coopetition-The role of absorptive capacity and appropriability. Journal of Product Innovation Management, 30(1), 154-169. doi.org/10.1111/j.1540-5885.2012.00956.x

Ritala, P., Agouridas, V., Assimakopoulos, D., \& Gies, O. (2013). Value creation and capture mechanisms in innovation ecosystems: A comparative case study. International Journal of Technology Management, 63(3-4), 244-267.

doi.org/10.1504/ijtm.2013.056900 
Ritala, P., Golnam, A., \& Wegmann, A. (2014). Coopetition-based business models: The case of Amazon.com. Industrial Marketing Management, 43(2), 236-249. doi.org/10.1016/j.indmarman.2013.11.005

Ritala, P., Kraus, S., \& Bouncken, R. B. (2016). Introduction to coopetition and innovation: Contemporary topics and future research opportunities. International Journal of Technology Management, 71(1-2), 1-9. doi.org/10.1504/ijtm.2016.077985

Roberts, J. (2000). From know-how to show-how? Questioning the role of information and communication technologies in knowledge transfer. Technology Analysis \& Strategic Management, 12(4), 429-443. doi.org/10.1080/713698499

Selander, L., Henfridsson, O., \& Svahn, F. (2010). Transforming Ecosystem Relationships in Digital Innovation. International Conference for Information Systems, 138, 1-15.

Simpson, P. (2019). Ecosystems: What are they and why should you care? Management Today. Retrieved from https://www.managementtoday.co.uk/ecosystems-whycare/future-business/article/1586299_Accessed 18 August 2019.

Spender, J. C. (1996). Making knowledge the basis of a dynamic theory of the firm. Strategic Management Journal, 17(S2), 45-62. doi.org/10.1002/smj.4250171106

Stockdale, S. (2015). Want to know the secret of success? Help your competitors. The Guardian, Women in Leadership, p.1.

Szulanski, G. (1996). Exploring internal stickiness: Impediments to the transfer of best practice within the firm. Strategic Management Journal, 17(S2), 27-43. doi.org/10.1002/smj.4250171105

Tether, B. S. (2002). Who co-operates for innovation, and why: An empirical analysis. Research Policy, 31(6), 947-967. doi.org/10.1016/S0048-7333(01)00172-X 
Thomason, S. J., Simendinger, E., \& Kiernan, D. (2013). Several determinants of successful coopetition in small business. Journal of Small Business \& Entrepreneurship, 26(1), 15-28. doi:10.1080/08276331.2012.761800

Tidström, A. (2018). Coopetitive tensions. In A. S. Fernandez, P. Chiambaretto, F. Le Roy, \& W. Czakon, (Eds.), Routledge Companion to Coopetition Strategies (pp. 149-157). New York City, NY: Routledge.

Tsang, E. W. (2002). Acquiring knowledge by foreign partners from international joint ventures in a transition economy: Learning-by-doing and learning myopia. Strategic Management Journal, 23(9), 835-854. doi.org/10.1002/smj.251

Van Wijk, R., Jansen, J. J., \& Lyles, M. A. (2008). Inter-and intra-organizational knowledge transfer: A meta-analytic review and assessment of its antecedents and consequences. Journal of Management Studies, 45(4), 830-853. doi.org/10.1111/j.1467-6486.2008.00771.x

Wang, Z., \& Wang, N. (2012). Knowledge sharing, innovation and firm performance. Expert Systems with Applications, 39(10), 8899-8908. doi.org/10.1016/j.eswa.2012.02.017

Woodside, A. G. (2013). Moving beyond multiple regression analysis to algorithms: Calling for a paradigm shift from symmetric to asymmetric thinking in data analysis and crafting theory. Journal of Business Research, 66(4), 463-472. doi.org/10.1016/j.jbusres.2012.12.021

Woodside, A. G. (2014). Embrace• perform• model: Complexity theory, contrarian case analysis, and multiple realities. Journal of Business Research, 67(12), 2495-2503. doi.org/10.1016/j.jbusres.2014.07.006

Yami, S., \& Nemeh, A. (2014). Organizing coopetition for innovation: The case of wireless telecommunication sector in Europe. Industrial Marketing Management, 43(2), 250260. doi.org/10.1016/j.indmarman.2013.11.006 
Yami, S., Castaldo, S., Dagnino, B., \& Le Roy, F. (2010). Coopetition: Winning strategies for the 21st century. Cheltenham, UK: Edward Elgar Publishing. 


\section{Table 1:}

\section{Interview questions}

\begin{tabular}{|c|c|c|}
\hline Condition & Initial questions and semantic differentials & $\begin{array}{l}\text { Follow-up questions (for each } \\
\text { condition based on response to } \\
\text { initial question) }\end{array}$ \\
\hline $\begin{array}{l}\text { Tacit/Explicit } \\
\text { Knowledge }\end{array}$ & $\begin{array}{l}\text { Would you say the knowledge you gained from your ecosystem } \\
\text { partner was information highly personal and experiential, specific } \\
\text { to your ecosystem partner (tacit)? Or was it more technical } \\
\text { knowledge, in the form of perhaps manuals or policies (explicit)? }\end{array}$ & \\
\hline Understanding & $\begin{array}{l}\text { Please rate your level of understanding of the information you } \\
\text { received, ranging from low level to high level. }\end{array}$ & \\
\hline $\begin{array}{l}\text { Low Causal } \\
\text { Ambiguity }\end{array}$ & $\begin{array}{l}\text { To what extent do you believe that the origins of the information } \\
\text { gained from your ecosystem partner were unambiguous, ranging } \\
\text { from unclear to clear? }\end{array}$ & $\begin{array}{l}\text { Could you please tell me a bit } \\
\text { more about why that is? }\end{array}$ \\
\hline Trust & $\begin{array}{l}\text { To what extent do you believe that you have a trustworthy } \\
\text { relationship with your ecosystem partner, ranging from } \\
\text { untrustworthy to trustworthy? }\end{array}$ & $\begin{array}{l}\text { Why didn't you choose a } \\
\text { lower/higher rating? }\end{array}$ \\
\hline Tie Strength & $\begin{array}{l}\text { To what extent do you believe that you have a strong relationship } \\
\text { with your ecosystem partner, ranging from weak to strong? }\end{array}$ & $\begin{array}{l}\text { Can you give me an example of } \\
\text { this? }\end{array}$ \\
\hline $\begin{array}{l}\text { Cultural } \\
\text { Similarity }\end{array}$ & $\begin{array}{l}\text { To what extent do you believe that your organization possesses an } \\
\text { organizational culture similar to that of your ecosystem partner, } \\
\text { ranging from dissimilar to similar? }\end{array}$ & \\
\hline $\begin{array}{l}\text { Learning } \\
\text { Intent }\end{array}$ & $\begin{array}{l}\text { To what extent do you believe that your organization possesses a } \\
\text { willingness to learn new knowledge, ranging from unwilling to } \\
\text { willing? }\end{array}$ & I'd like to hear more about... \\
\hline $\begin{array}{l}\text { Absorptive } \\
\text { Capacity }\end{array}$ & $\begin{array}{l}\text { To what extent do you believe that your organization absorbs and } \\
\text { acquires new knowledge, ranging from un-absorptive to } \\
\text { absorptive? }\end{array}$ & \\
\hline
\end{tabular}


Table 2:

Solutions for coopetitive partnerships

\begin{tabular}{|c|c|c|c|c|}
\hline \multirow[b]{2}{*}{ Configuration } & \multicolumn{4}{|c|}{ Solution } \\
\hline & 1 & 2 & 3 & 4 \\
\hline Tacit Knowledge & $\otimes$ & $\bullet$ & $\bullet$ & $\bullet$ \\
\hline Explicit Knowledge & $\bullet$ & $\bullet$ & $\bullet$ & $\bullet$ \\
\hline Understanding & & $\bullet$ & $\bullet$ & $\otimes$ \\
\hline Causal Ambiguity & $\bullet$ & $\bullet$ & $\bullet$ & $\bullet$ \\
\hline Trust & $\bullet$ & $\bullet$ & & $\otimes$ \\
\hline Tie Strength & $\bullet$ & $\bullet$ & $\bullet$ & $\bullet$ \\
\hline Cultural Similarity & $\otimes$ & O & 0 & O \\
\hline Learning Intent & $\bullet$ & 0 & 0 & 0 \\
\hline $\begin{array}{l}\text { Absorptive Capacity of } \\
\text { recipient firm }\end{array}$ & $\bullet$ & & $\bullet$ & $\otimes$ \\
\hline Consistency & 0.98 & 0.92 & 0.91 & 0.96 \\
\hline Raw coverage & 0.27 & 0.42 & 0.33 & 0.13 \\
\hline Unique coverage & 0.21 & 0.15 & 0.06 & 0.06 \\
\hline Overall solution coverage & 0.75 & & & \\
\hline Overall solution consistency & 0.94 & & & \\
\hline
\end{tabular}

Note: Black circles $(\mathbf{O})$ indicate the presence of a condition; crossed out circles $(\otimes)$ indicate the absence of a condition. Large circles represent core conditions; small circles represent peripheral conditions; blank spaces indicate redundant conditions. 
Table 3:

Solutions for non-competitive partnerships

\begin{tabular}{lcccc}
\hline & \multicolumn{5}{c}{ Solution } \\
\hline Configuration & 1 & 2 & 3 & 4 \\
Tacit Knowledge & $\bullet$ & $\bullet$ & $\bullet$ & $\bullet$ \\
Explicit Knowledge & $\bullet$ & $\bullet$ & $\otimes$ & $\bullet$ \\
Understanding & $\bullet$ & $\bullet$ & $\otimes$ & $\bullet$ \\
Causal Ambiguity & $\otimes$ & $\bullet$ & $\bullet$ & $\bullet$ \\
Trust & $\bullet$ & $\bullet$ & $\otimes$ & $\otimes$ \\
Tie Strength & $\bullet$ & $\bullet$ & $\bullet$ & $\otimes$ \\
Cultural Similarity & & $\otimes$ & $\otimes$ & $\otimes$ \\
Learning Intent & $\bullet$ & $\bullet$ & $\otimes$ & $\bullet$ \\
Absorptive Capacity of & $\otimes$ & & $\otimes$ & $\otimes$ \\
recipient firm & 0.94 & 0.88 & 0.95 & 0.95 \\
Ransistency coverage & 0.33 & 0.32 & 0.16 & 0.16 \\
Unique coverage & 0.24 & 0.22 & 0.11 & 0.07 \\
\hline Overall solution coverage & 0.75 & & & \\
Overall solution consistency & 0.93 & & & \\
\hline
\end{tabular}

Note: Black circles $(\Theta)$ indicate the presence of a condition; crossed out circles $(\otimes)$ indicate the absence of a condition. Large circles represent core conditions; small circles represent peripheral conditions; blank spaces indicate redundant conditions. 


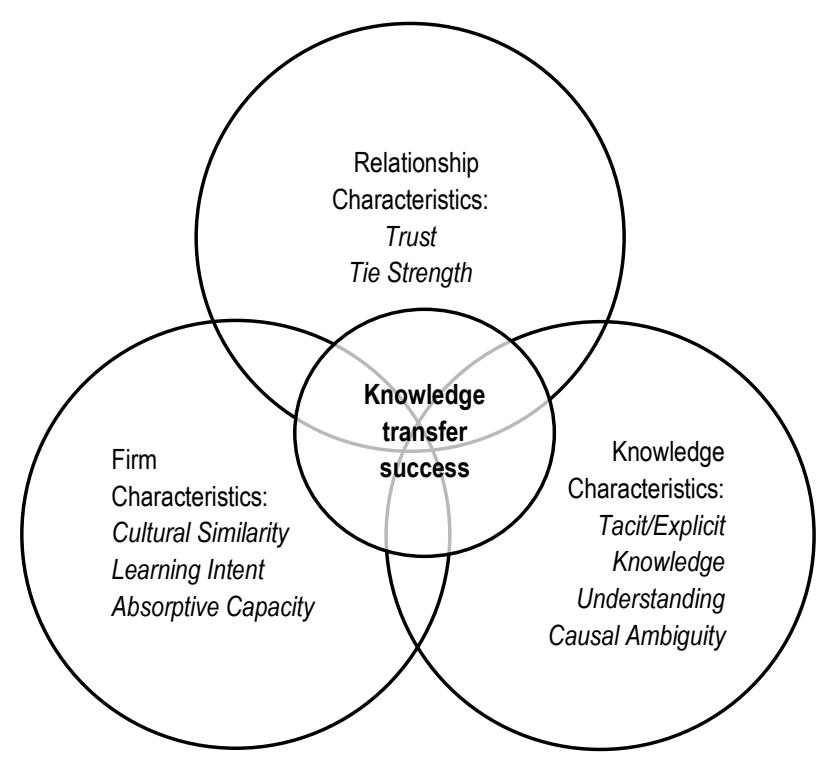

Figure 1:

Conceptual Framework 